\title{
The rights of Lebanese expatriates and their political engagement with the homeland
}

Aida Casanovas - Universitat Pompeu Fabra

(1) 0000-0002-3362-2442

Nassima Kerras - Universitat Pompeu Fabra

(1) 0000-0002-9700-8257

Recepción: 21.07.2020 | Aceptado: 30.09.2020

Correspondencia a través de ORCID: Aida Casanovas i Oliveras

iD 0000-0002-3362-2442

Citar: Casanovas, A., \& Kerras, N. (2020). The rights of Lebanese expatriates and their political engagement with the homeland. REIDOCREA, 9, 173-191.

\begin{abstract}
Attention to diasporas has traditionally come from their transnational role as providers of developmental aid while neglecting the political and civil rights of expatriates and their potential as governance actors. In an era of global mobility, there is an uncomfortable research gap in the relationship between diasporas and their states. The implications can only be appreciated with the lens of Lebanese scholar Paul Tabar's 'diaspora-specific field' (2019). Through the analysis of Lebanese diasporic relations during the Lebanese October Revolution 2019, we evaluate the importance of emigration policies and inclusion of the diaspora in decision-making processes in the homeland to build sustainable diaspora-state relations, reduce inequalities between resident and non-resident citizens and build peace, justice and strong institutions as urged by SDGs 10 and 16. We provide real evidence of the struggles and political engagement of the diaspora during the Thawra (revolution) with a sample of expatriates based in Catalonia and the political agenda of Meghterbin Mejtemiin, the network bringing Lebanese expatriates together to support the revolution from abroad, and that of Associació Catalunya-Líban. We demonstrate through Lebanon's case that diasporas can be a nation-state building partner and help to recapture state sovereignty from the hands of private interests' groups.
\end{abstract}

Keywords: Diasporic Relations, Lebanese Revolution 2019, Emigration Policies, Rights of Expatriates, Nation-State Building

\section{Los derechos de los expatriados libaneses y su compromiso político con el país de origen}

Resumen: A menudo, las diásporas han llamado la atención por su enorme papel como proporcionadoras de recursos para el desarrollo de sus países de origen, olvidando sus derechos políticos y civiles, así como su potencial como actores de gobernanza de la migración. En una era de movilidad global, es sorprendente encontrar un vacío en el mundo de la investigación sobre las relaciones entre los estados y sus comunidades diaspóricas. Las implicaciones derivadas sólo se pueden percibir a través del 'diasporaspecific field' acuñado por el libanés Paul Tabar (2019). Partiendo del análisis de las relaciones diaspóricas surgidas durante la Revolución Libanesa de 2019, evaluamos la importancia de las políticas de emigración estatales y la inclusión de las diásporas en procesos de toma de decisiones que construyan relaciones sostenibles entre el estado y la diáspora y reduzcan las desigualdades entre los residentes y los expatriados para la construcción de la paz, justicia e instituciones fuertes que los ODS 10 y 16 instan. Este estudio proporciona claras evidencias de la lucha y compromiso político de la diáspora libanesa durante la Thawra (revolución) mediante una muestra de expatriados residentes en Catalunya, las opiniones de la representante de la plataforma Meghterbin Mejtemiin en los Países Bajos y del presidente de la Associació Catalunya-Líban. El caso de El Líbano demuestra que las diásporas pueden contribuir a la vigorización del estado-nación y la reconquista del poder estatal de las manos de grupos de interés privado.

Palabras clave: relaciones diaspóricas, Revolución Libanesa 2019, políticas de emigración, derechos de los expatriados, construcción del estado-nación

\section{Introduction}

The proposition that transnational migration flows challenge the Nation-state system has become widely accepted and rarely uncontested. Pearlman (2014: 64), for instance, argues that there is a correlation between state weakness and the intensity and nature of the relations that unfold between diasporas and their homelands; when the state is weak, the diaspora circumvents official mechanisms of control (Pearlman, 2014: 36) "in ways that are reinforcing rather than transformative" of the system (Pearlman, 2014: 65). 
Nevertheless, diasporas are not the only actor eroding national sovereignty. In fact, backstage politics controlling translational mobility might prove more undermining.

Overall, diasporas are an underexplored actor in the field of migration studies, often treated as a side-effect or characteristic of transnationalism rather than as a process in itself (Tabar, 2016: 257). In the best of cases, the interest in diasporas has come from their well-known supply of remittances or in relation to integration issues in their host countries. But their contributions go far beyond money transfers, as they also make investment operations, transfer technology, skills, and cultural norms that help develop their homelands (Newman \& Plaza, 2013: 4-6).

The 2030 Agenda for Sustainable Development is the first transversal call to governments and non-governmental actors to "leave no one behind" in the race for sustainable development. This includes migrants, which for the first time are disaggregated by target 10.7, that encourages governments "to facilitate orderly, safe, regular and responsible migration and mobility of people, through the implementation of planned and well-managed migration policies" to reduce inequalities within and among countries (SDG 10) (United Nations, 2015). It is understood by 'safe, orderly and regular migration' the commitment of States so that "human dignity and well-being of migrants are upheld, their rights are respected, protected and fulfilled and the risks associated with the movement of people are acknowledged and mitigated", as defined by the International Organization for Migration (2019: 148). We have taken this general target as a reference and narrowed it down to the case of emigrants from Lebanon.

The point of departure of this survey is the Lebanese Revolution of October 2019, a movement that has questioned the rhizomatic corruption of the political class and its private networks, sectarianism, colonial legacies, clashing national narratives and stereotypes. The worst financial crisis ever lived by the country since the end of the Civil War (1975-1990) has awakened a class awareness that transcends all kinds of divisions. The Thawra -as the uprising is known in Arabic- has also included the diaspora. This is far from being the first time that the diaspora backs social claims at home, but it is so after the achievement of outside-country voting (Houri, 2019). Its involvement is the response to decades of unaddressed brain drain and lack of migration policies that guarantee its equal rights among all citizens.

\section{Objectives and hypothesis}

We contend that the Thawra has been the cornerstone of 'diasporic relations' between the expatriates and residents in Lebanon in the understanding of French sociologist Bourdieu (1989) and the 'diaspora-specific field' by Lebanese scholar Tabar (2019). The 'field' is a notion defined by Bourdieu (1989: 375) as the power struggle between the state and expatriates over institutional functions of the state. The difference with transnational relations is that diasporic relations take place only in the public realm, whereas the former can develop throughout private spheres like the family or friends. We also endorsed Lebanese scholar Fakhoury's forecast (2018) that the achievement of outside-country voting might have opened a new period of diasporic political engagement. In light of this, the aim of our research has been two-fold. Also, we wanted to verify if diasporic relations are state-eroding in times of political crisis like the Thawra and during global crisis like the one unleashed by COVID- 19.

On the one hand, we described the evolution of the relations between the Lebanese diaspora and its homeland, the actor that should regulate remittances and protect its political and civil rights. On the other hand, we examined the importance and possible mechanisms to ensure expatriates access to smooth, responsible, participatory and 
inclusive decision-making processes at all levels, as urged by the United Nations' SDG 16 (United Nations, 2015).

\section{Methodology}

This article is based on the analysis of the ongoing development of the Revolution in connection to past events and a survey answers by nineteen Lebanese expatriates in Catalonia that was disseminated through social media between April and May 2020. Two versions were used, one in Catalan and one in English, that were later on merged. The participants were informed of the purposes of the survey before the completion of the form and were provided with an email of contact in case they had any doubts or wanted to make any extra contributions. The survey consisted of 47 questions of different nature: multiple-choice, open-ended, categorical and Likert questions related to their expatriation experiences, reasons for emigration, perception about Lebanese politics and their engagement with the Thawra, including the indicators for the SDGs and the scaling defined by the UN: Not at all; Very little; Some; A lot; A great deal (UN DESA \& IAEG, 2019).

The 2030 Agenda sets as indicators of target 16.7 "the proportion of positions (by sex, age, persons with disabilities and population groups) in public institutions (national and local legislatures, public service, and judiciary) compared to national distributions" and "the proportion of the population who believe decision-making is inclusive and responsive, by sex, age, disability and population group" (United Nations, March \& September 2019). To avoid contributing to the sectarian narrative that the Thawra is fighting and because the corruption and lack of data make impossible any objective analysis of the proportions in which expatriates are represented at state institutions, we dismissed the first indicator and adapted the second to the diaspora. The central questions to this indicator were "How much would you say that the political system allows you to have a say in what the government does?" [Figure 1] and "How much would you say that the political system allows people like you to have an influence on domestic politics?" [Figure 2].

UN Indicator SDG 16.7.2.a

How much would you say that the political system in Lebanon allows people like you to have a say in what the government does?

19 respostes
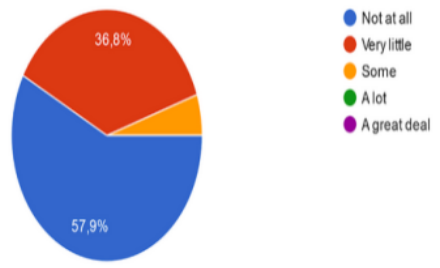

Figure 1: Results of the barometer question for UN Indicator 16.7.2.a
UN Indicator SDG 16.7.2.b

How much would you say that the political system in Lebanon allows people like you to have an influence on domestic politics?

19 respostes

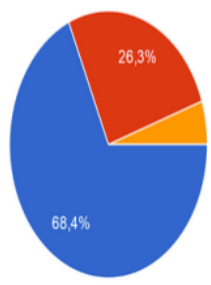

- Notatall

- verylittle

Alot

- Agreatdeal

Figure 2: Results of the barometer question for UN Indicator 16.7.2.a 
As for target 10.7, we have also taken only one of the two barometres proposed by the UN: the implementation of well-managed migration policies because we were mostly interested about the political contributions of emigrants and returnees than economic remittances. Hence, we skipped Domains 1,5 and 6 dealing with non-nationals and we applied Domains 2, 3 and 4 instead, that deal with evidence-based policies, cooperation and partnership in the formulation of migration policies and the social well-being of all migrants. The policy domains are grounded on the IOM's Migration Governance Framework (MiGOF) that was passed in 2015 by 157 countries (UN DESA, IOM \& OECD, 3 2019) without the Lebanese support, as it is not party nor observer to the IOM.

Tables 1: Description of selected domains for SDG indicator 10.7.2 (Source: https://url2.cl/LDEli)

Domain 2: $\begin{aligned} & \text { Does the Government have any a. A dedicated Government agency to implement national } \\ & \text { of the following institutions, } \\ & \begin{array}{l}\text { policies or strategies to govern } \\ \text { immigration or emigration? }\end{array}\end{aligned}$
$\begin{aligned} & \text { b. A national policy or strategy for regular migration pathways, } \\ & \text { including labour migration } \\ & \text { c. A national policy or strategy to promote the inclusion or } \\ & \text { integration of immigrants } \\ & \text { d. Formal mechanisms to ensure that the migration policy is } \\ & \text { gender responsive } \\ & \text { e. A mechanism to ensure that migration policy is informed by } \\ & \text { data, appropriately disaggregated }\end{aligned}$

Domain 3: Does the Government take any a. An inter-ministerial coordination mechanism on migration of the following measures to foster cooperation among countries and encourage

b. Bilateral agreements on migration, including labour migration stakeholder inclusion and participation in migration c. Regional agreements promoting mobility policy?
d. Agreements for cooperation with other countries on return and readmission
e. Formal mechanisms to engage civil society and the private sector in the formulation and implementation of migration policy
Domain 4: Does the Government take any a. Align, through periodic assessments, labour migration policies of the following measures to with actual and projected labour market needs maximize the positive development impact of migration and the socioeconomic well-being of b. Facilitate the portability of social security benefits
c. Facilitate the recognition of skills and qualifications acquired migrants? abroad
d. Facilitate or promote the flow of remittances
e. Promote fair and ethical recruitment of migrant workers

Moreover, we interviewed Tracy Saad, a representative of the Lebanese platform Meghterbin Mejtemiin in The Netherlands about the role of the network organising the demonstrations in support of the Revolution abroad and Ghassan Saliba, president of Associació Catalunya-Líban, an organisation raising awareness in the Catalan context since 1982 about the Lebanese reality and running solidarity projects on Lebanese soils.

\section{Global and regional situation vis-à-vis SDGs 10 and 16}

The different understandings for 'expatriate', 'emigrant', 'migrant' or 'diaspora' at the international level (Migration Data Portal, 2020) obscure their legal status and difficult estimations of how many expatriates are around the world. According to a study by 
Finaccord (2017), that has a broad understanding of 'expatriation', there were 66.2 million expatriates 4 worldwide in 2017 and it forecasted an increase in 20 million $(+1.13 \%)$ by 2021 and an increase from $25.7 \%$ to $28.5 \%$ relative to the total immigrant population. This expanding size 5 begs an analysis of their rights and mechanisms of governance.

The primordial rights of expatriates emanate from their human condition. However, their rights as citizens or members of a national community abroad are not clear cut. Migration rights in the international arena are basically stipulated in relation to labour. But when it comes to expatriates who are not submitted to a labour contract, like students or trainees, for instance, there is a legal vacuum, as reflected in the International Convention on the Protection of the Rights of All Migrant Workers and Members of their Families (1990).

As we will see later on, diasporas are a political actor, and yet they are not internationally recognised as a legal unit with the right to representation at homeland institutions. However, they have the right to freedom of association as migrants in their host countries as recognised by Article 26 of the ICRMW (1990). The same applies to other political rights like the one to 'peaceful assembly' enacted by Article 21 of the International Covenant on Civil and Political Rights or that of 'freedom of association' (Article 22). Only Article 25 of the ICCPR referring to the electoral rights of citizens points out more clearly at the State of citizenship as the guardian of the right to participate in national decisionmaking processes and yet it does not specify how it should be done and what should be the status of expatriates in relation to it. So far, Lebanon is not party nor signatory of ICRMW but it is a party to the ICCPR (UN General Assembly, 1966).

Hence, there is no binding international agreement on migration rights that enshrines the right to representation of diasporas in their home country; it is at the (moral) discretion and interest of each State (International Justice Resource Center, n.d.). Likewise, it is not written anywhere that States must have any policies regulating emigration and immigration, although SDG 10 and several meetings like the first Annual Diaspora Forum in May 2018 and the Global Compact for Migration have been pushing for their implementation (IOM, 2018). It is worth noting that no representation of the Lebanese diaspora attended the meeting, while Tunisia, Algeria, Jordania, Palestine and Morocco were present (IOM, 2018, May 31).

\section{Lebanon and diasporas from the MENA region}

Lebanon is part of the MENA region, which largely coincides with what is usually known as the 'Arab world', although Lebanese heritage is ambivalently Arab and European. Decades of political upheaval and colonial legacy are responsible for an Arab diaspora estimated in 20 million: $5 \%$ of the regional population and $10 \%$ of the world's population. Approximately half of them have traditionally migrated to other countries within the region -mainly the Gulf- followed by Europe (including Turkey) and North America. Nowadays, Syria, Egypt and Morocco lead the ranking of most emigration-prone countries in the region.

Worldwide economic remittances reached a record of $\$ 554$ billion in 2019 (World Bank Group \& KNOMAD, 2020: 7), being Egypt the 5th country in the list of top remittance recipient countries with $\$ 26.8$ billion and the first of the region before Lebanon. Because of 7 the economic slowdown prompted by COVID-19 remittances to the region are expected to fall by nearly 20\% this year (World Bank Group \& KNOMAD, 2020: 24). These economic efforts have invigorated requests for enhanced political participation of the diaspora at home to express their "vision, difficulties and needs" (Sarsar et al., 2019: $56)$. 
As for their major political contributions, they must be analysed in the context of the Arab Springs, a crisis of the state (Kassir, 2019: 25). Although their outcomes have been different in each country, these uprisings have spurred long-distance activism, motivated the return of a remarkable amount of expatriates after the fall of authoritarian regimes and the creation of spaces for free speech and public debate (Sarsar et al., 2019: 57). During the uprisings, expatriates organised demonstrations, carried out cyberactivism and lobbied the international community. In the aftermath, they have also proved to be effective peacemakers and mediators (Sarsar et al., 2019: 62-63). Overall, they changed the conception that people and governments have on diasporas (Sarsar et al., 2019: 71).

During the revolutions, authoritarian regimes also silenced the diasporic opposition by threatening them of retaliation against their beloved ones and hindering the unity of their claims (Sarsar et al., 2019: 59-61). After the uprisings, some governments incorporated outside-country voting as a democratisation façade to legitimise their power and to control the diasporas, not as real altruistic concessions of political rights (Sarsar et al., 2019: 62). The exception in all cases is Tunisia, the only country that transitioned to full democracy.

One of the conclusions that can be drawn from the 'Arab Springs' is that democratisation processes are not limited to universal suffrage, which is of limited effectiveness without transparency, broad accountability and respect for human rights (Sarsar et al., 2019: 70). However, the inclusion of diasporas might pluralise the political spectrum and decentralise the state power, providing a breach to incorporate other non-state actors in processes of governance (Craven, 2018: 12), like diasporas (Craven, 2018: 19).

Decentralising state power does not necessarily mean to undermine it. Instead, it can entangle with state-building by gathering more pro-state partners. That is why citizens and diasporas should have a voice in decision-making processes (Sarsar et al., 2019: 62-63). It is absolutely in the interest of developing countries. That can be achieved with comprehensive migration policies and institutions, a common shortcoming of MENA states. In fact, few governments have deployed ministries dedicated to expatriates even if some have facilitated dual citizenship to their expatriates as well as money transfers.

Although not everyone agrees, as we will explore more later on, the Lebanese Revolution might be considered a deferred Arab Spring. According to Lebanese Professor at SOAS Gilbert Achcar, the Thawra has learned from the model of grassroots platforms developed by the Sudanese revolution of 2018-2019, that managed to overthrow President Omar al-Bashir after three decades in power thanks to a very strong network of associations and professionals from all sectors (Achcar, 2019). Besides, the Thawra is part of a series of 'Diaspora Springs' (Sarsar, 2019: 59) that according to Achcar (2019) will continue for some decades. It is not a simple confrontation against sectarian groups but the symptom of a crisis of the neoliberal system after the 2008 recession (Achcar, 2019) when states have been either dismantled or privatised by an oligarchy. This debilitation of the state has been compensated by strengthened repressive apparatuses to control the furious crowds (Maksidi, 1997: 697).

\section{Historical background on Lebanese expatriation}

Modern Lebanese emigration began in the mid-19th century due to conflicts between the Druze and Maronite Christians and by the economic collapse of a European-oriented silk market. This emigration was the founder of the Lebanese diaspora in Europe, and North and South America. The bulk of this wave were illiterate men that managed to build a Lebanese middle-class at their homeland thanks to remittances and investment in basic infrastructures and social projects (Waters et al., 2019). The diasporic communities that 
were established those days made possible the sponsorship of more migrants throughout the 20th century due to political upheavals at a national and regional level. Current brain drain has to be traced to the economic recession triggered by the Lebanese Civil War (1975-1990) and its long-lasting effects until today. Post-war decade are characterised by the emigration of the best-educated youth in the Middle East (Dibeh \& Fakih \& Marrouch, 2017: 8).

\section{Migration policies}

Lebanon's population census from 1932 has never been updated for fear that after years of emigration and demographic changes the power-sharing formula would be destabilised. Yet both Muslims and Christians for a long time demanded to include the descendants of expatriates in a competition for votes and state resources, believing they outnumbered one another (Raad, 1998). Lack of data is an obstacle to sustainable diasporic relations. However, political participation is not the most prominent kind of engagement that the Lebanese diaspora has historically undertaken with its state.

Most relations with the diaspora are channelled through political parties and other sectarian CSOs that act on behalf of the seized state. These organisations are responsible for maintaining or awakening an interest in expatriates for Lebanese politics but they also reinforce sectarian agendas. Another important actor mediating between the diaspora and its homeland has been the Lebanese "extended family" (the relatives beyond the nuclear family), which is the backbone of the clan in Lebanon and a sponsor for potential emigrants (Hourani, 2007: 5). The banking sector has also been very active targeting Lebanese abroad to gather new expatriate clients necessary to sustain the national economy (Fakhoury, 2018: 3). It is important not to confuse these activities transnational in scope- with diasporic relations.

The polarization of the diaspora and its contribution to political animosity at home is partly a consequence of the inexistence of a consistent nationwide migration policy to deal with the émigrés in equal terms. As a survey concluded, if something similar to a migration policy exists, it is messy and barely implemented and rather works against the interests of both the diaspora and homeland (Chaaban, 2018: 11). Also, there is a lack of coordination between the multiple state authorities dealing with migration issues: the General Directorate of the General Security, the Ministry of Foreign Affairs and Emigrants and the Ministry of Interior (Chaaban, 2018: 18).

The Ministry of Foreign Affairs and Emigrants is the main authority sustaining and encouraging the involvement of the diaspora in national development. It issues reports about the characteristics of Lebanese diasporic communities and it informs them about the opportunities to invest at home. It also backs up cooperation among different religious groups abroad, the creation of associations and unions and promotes regular visits by the diaspora at home (Jagarnathsingh, 2018: 65; DiBartolomeo \& Fakhoury \& Perrine, 2010: 8). However, not all diasporic communities enjoy the same governmental support abroad because there still are regions that do not enjoy diplomatic missions or representative bodies as confirmed by Ghassan Saliba.

All in all, on the one hand, the Lebanese State has programmes to attract the diaspora investment in the development of the country but on the other its intentions to entrust it any decision-making role remain weak. Emigration policies help states extend their power over diasporic communities and manage their impact and contributions so that more people can benefit from them. In the absence of emigration policies, the larger the diaspora becomes, the more difficult it will be to control it and to materialise its remittances into change. 


\section{Current situation}

In 1990, after 15 years of militia war, Lebanese elites unilaterally decided to turn the page and lay the arms down. Savage multimillionaire investment by the militias and warlords managed to clear out the Lebanese capital of war debris but not intersectarian rancours. No reconciliation at the popular level was promoted by the state and amnesia became the general arrangement (Ghosn \& Khoury, 2011: 13). Thus, the war in Lebanon is not over. It is a latent force in daily collective attitudes, prejudices, loyalties, economic dynamics and government policies. The so-called "post-war decades" are not but a continuation of the war through other means. The October Revolution is a call to end this protracted conflict.

On 6 May 2018, Lebanon held its first elections since 2009, when a legislature split took place between two blocs named March 8 and March 14. These two movements emerged in the Cedar Revolution of February 2005, upon the assassination of Prime Minister Rafik Hariri with divergent national projects and views on the Syrian tutelage of Lebanon since The Taif Agreement (1990). While March 8 supported the Syrian intervention in the country as a shield from Western and Israeli influence, March 14 criminalised the Syrian tutelage and called for its withdrawal, which was accomplished two months later. March 8 was backed by Iran and Syria while March 14 was supported by Saudi Arabia and Western countries. These two movements added more polarisation on top of traditional ethno-religious divisions.

Lebanon's electoral legislation follows a consociational structure that attempts to be representative of the demographic weight of the different religious communities. This power-sharing system was established in 1860 by European powers and was amended by The Taif Agreement. The negotiation was mediated by 72 surviving MPs and several foreign powers (Egypt, Syria, France, Iran and the United States); Christians lost the historical majority bestowed by the French since in the 19th century when they outnumbered the Muslims. Taif is responsible for the institutionalisation of sectarianism, a "temporary solution" from the National Pact of 1943 (El Rajji, 2014: 1-2; The Taif Agreement, 1989).

The basis of the current electoral law dates back from Taif, but the Lebanese diaspora was not included until years after. Proposals to include them in the electorate were not taken seriously until 2005 (Nasrallah, 2016: 44-45) and the final bill was not approved until 2008. In 2009 elections, non-residents could already vote but only in Lebanon. The electoral law that regulated the 2018 elections (passed in June 2017), eventually introduced outside-country voting. It was a long-awaited achievement, given that the first talks began in the 1940s (Nasrallah, 2016: 40). The ACL petitioned in 1992 this right with the conviction that it would reduce vote-buying by means of plane tickets in exchange for votes. Fakhoury (2018) suggested that it might open a new era of diaspora engagement in Lebanese politics.

Since May 2016 descendants of the Lebanese diaspora can also apply for their ancestral citizenship (Nasrallah, 2016: 48). However, naturalised Lebanese cannot vote before 10 years (National Democratic Institute, 2018: 14). According to the Lebanese Constitution women and men are equal before the civil law (Article 7), although the 15 different personal status contradicts it and women cannot pass their citizenship down. However, both women and men can vote from the age of 21 (National Democratic Institute, 2018: 10-13). In 2018, 3.6 million Lebanese women and men were called to vote (an average turnout of 48 . $02 \%$ ), out of which 82,965 were expatriates based in 40 different countries (Ajroudi, 2018). 
Outside-country voting could be done through embassies and consular missions with previous registration, although it was not that easy for everyone because as mentioned before, not all countries have Lebanese diplomatic missions and not all religions enjoy the same status abroad. To some extent, this is the case of Catalonia too. According to Mr Saliba, only 20 Lebanese in Catalonia voted because they had to go to Madrid, as the minimum to open another polling centre was 3,000 voters and only 2,000 registered. Eventually, only 46,799 participated and two-thirds were men (National Democratic Institute, 2018: 13). Tracy Saad, spokesperson of the expatriate network Meghterbin Mejtemiin ("Expatriate Citizens") in The Netherlands expressed that poor participation is because people are waiting to vote for something new. And Ghassan Saliba declared that the personalist system discourages the diaspora vote, as oftentimes expatriates do not know the candidates of their ancestral region.

In 2018, Article 122 of the new electoral law stipulated that six seats would be added to the current 128 deputies in the representation of the expatriates belonging to the 6 major religious groups (Ministry of Information, 2018). Eventually, this article did not enter into force for fear of the uncertain impact on sectarian quotas and it is pending to be applied in the next elections. For the time being, non-residents are counted as any other citizen.

The reasons for the incorporation of the diaspora in the electorate are controversial. As Tracy Saad expressed, there is confusion among the expatriate community on why suddenly politicians showed interest for them; she guessed that it is part of their race for more votes. During periods of conflict or political instability, the ties between the two wings were fortified by the financial dependency of the residents on the diaspora (Tabar et al., 2012: 11). And more interestingly, the role of the diaspora upgraded from a discrete status as an aid provider to undertake an active political role (Tabar, 2012: 18).

Might the October Revolution be the point of no return that both Tabar (2019) and SkulteOuaiss (LAU News, 2015) insinuate? 'Diaspora field' theory contends that 'diasporic relations' happen at the moment that diasporic individuals cooperate in the public realm of society with the purpose of making an impact at the homeland. Bearing in mind this, it is plausible to say that the Thawra has developed diasporic relations, as both the diaspora and the homeland have mobilised politically and side by side and against the sectarian rhetorics. This would have been impossible without the consolidation of community identity among the members of the diaspora that did not exist intersectionality before the Thawra, according to Tracy Saad. What is new and common of this identity with the whole of the country is that for the first-time people identify themselves with the nation and civil values before the sect or confession, as Mr Saliba points.

In past episodes of anti-sectarian mobilisation (namely the episodes of 2011, 2013 and 2015 ) this social fragmentation had already shown symptoms of a meltdown but the elite knew how to play with the still very embedded communal identities to divide the protestors (Abi Yaghi, Catusse \& Younes, 2017). Besides, the role of the diaspora was not as massive if compared to the October Revolution (Achcar, 2019). Tracy Saad pinpointed that participation of the diaspora grew as much as that of any other group, not as a consequence of overseas voting. Thus, what makes the Thawra different is that it is the true first non-sectarian movement of the country in decades. The question is why precisely now and not before.

In June 2019, the government had announced a new series of austerity measures to cut the growing deficit and get access to international aid. The pack of measures included a $7 \%$ budget cut (Chehayeb, 2020, April 16) and an increase in bank deposit interests from $7 \%$ to $10 \%$ (Vohra, 2019). In September, the economic situation had worsened. Shortage of dollar currency -to which Lebanese pound is pegged since 1975 at the fixed rate of 
1507.5 LBP- took banks to ration cash withdrawals. The government did not give an official explanation for the sudden shortage of dollar, but some suggested that it was caused by a slowdown ${ }^{1}$ in the deposits of the diaspora, that have to bear with an exorbitant $15 \%$ interest rate with which the fiscal deficit and public debt are met (Vohra, 2019).

The announcement of new taxation over WhatsApp messages on 17 October was the straw that broke the camel's back. People started to claim for the resignation of the whole government under the chants "Kilon ya3ne kilon" ("All of them means all of them") and "Down with the capitalism". Another slogan that cannot be missed from the diaspora was "Leave so we can come back", that their compatriots in Lebanon replied with "Because

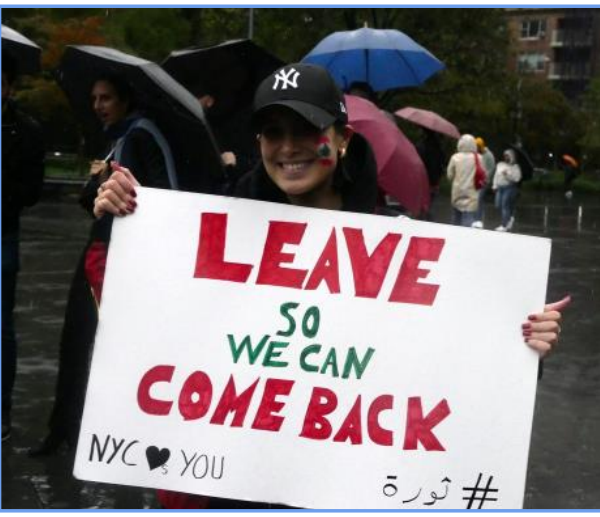
we 14 want you back" (Hage, 2020). Indeed, several are the expatriates who would like to resettle in Lebanon if there were decent opportunities to make a family (Yan, 2019). Tracy Saad, for instance, would like to have the opportunity to develop her professional career in Lebanon and the circular economy that she admires of The Netherlands and to put an end to the "WhatsApp family" model (a remote family) which many, like her, have.

Image: An expatriate in New York protests in support of the Thawra.

Lebanese elites have insinuated several times that people leave for pleasure. An example of this is President Michel Aoun's declaration on 12 November 2019 for the Lebanese TV channel Al-Mayadeen. He replied to the street chants targeting the ruling class that those who "see no decent people in this state, let them emigrate. They won't get into power" (Molana-Allen, 2019). Those declarations added even more fuel to the fire and triggered popular organisation to bring expatriates back on Independence Day (22 November) to prove that they were leaving because the government was not guaranteeing them a future at home (Sewell, 2019). Around 600 Lebanese, mainly from Europe and the Gulf, made it to Beirut, according to Saad. Meanwhile, several expatriate communities endorsed the claims from abroad thanks to the coordination of Meghterbin Mejtemiin. Up to 20 cities worldwide joined the Thawra (Zakhour, 2020).

A common element of the Thawra with past Arab Springs, is the tantamount role of social media in the organisation of protests and cooperative initiatives between the residents and the diaspora. However, this does not make the Thawra one more Arab Spring. Ghassan Saliba stressed that the main difference is that the Lebanese are not fighting against one regime, but fifteen. This fragmentation has historically prevented the deployment of Lebanese secret services targeting political enemies of the state. Repression and political manipulation -Ghassan explains- have come from other actors, mainly the parties. In Catalonia' case, however, perhaps because the community is quite small and was not profitable, there has not been much interference by parties according to Ghassan. Also, Saliba is hesitant to talk about the October 'intifada' (uprising) as a revolution because he believes that it is not over and that there is still a lot more to come. Political parties are not answering properly to street demands; they are rather trying to win time and causing more frustration. That is why he expects that the movement will go harsher in the following months.

1 "Lebanon: Protests over worsening economic crisis", 2019. 


\section{The aftermath of the Thawra}

The Thawra is not a revolution operating in a vacuum. Years of corruption, lack of government accountability, harsh austerity measures, unemployment, burdensome public debt and its derived social unrest are the fuel of a revolution that has revived the capacity to dream big for a little country. It has taken a few months for Lebanese people to learn and do for each other more than the ruling class has accomplished in decades. By means of peaceful, non-sectarian and inclusive demonstration they have unmasked and defied the obsolete tactics of the elite based on the "divide and rule" formula. People of all conditions have realised that they all are puppets of the ruling class, which could culminate in a renovated social contract.

In the previous section, we discussed how the 'current situation' embraces a wider time span than one would imagine, where the Thawra may be a final peak. But the Thawra is not over yet, as Tracy Saad and Ghassan Saliba agree. However, we can talk about the end of a first phase of the Thawra. After three consecutive months of daily protests, the formation of a new government cabinet on 21 January 2020 and the worsening financial crisis managed to dampen the protests in Lebanon. However, the revolution continued online, especially for the diaspora.

We asked Tracy Saad what the role of the expatriates in the revolution should be. Her opinion clashed with that of Ayah Bdeir, an expatriate who on 29 January 2020 asked the diaspora through social media not to stop supporting financially those at home in compensation for their physical absence in Lebanon (Bdeir, 2020). Saad declared that there is 'donors' fatigue' among expatriates and that there are other ways of contributing. The diaspora is relevant not only because it is larger than the resident population and can help conquer key political institutions or regenerate ideas based on the different international experiences by its members but also it can do backbone research on the political leaders that they are willing to hold accountable. Mr Saliba is also of the view that the role of the diaspora is to support the struggles that the residents suffer, but that the change agent is in the homeland.

The network Tracy Saad volunteers for is one of the many initiatives that were created during the revolution to inform about the development of the uprising amidst the lack of information or biased news released by party-owned local media. Other examples are Daleel al-Thawra, Assolta 4, Thawra TV or The Lebanese Revolution 2019 (Naji, 2020). All of them contributed to creating a new national narrative where Lebanese people are a single one against a common enemy: the ruling class (Ahmad, T. A., 2019). In the case of $\mathrm{MM}$, they also work to create a strong sense of family and expatriate community. Expatriates have always been solidary with their relatives but never before had they helped each other abroad as a cross-confessional community. This validates the proposition by Krawatzek and Müller-Funk (2020: 1016) that political remittances during historic events have the capacity to change narratives of belonging and start new identity constructions. Besides, it also proves Sökefeld (2006), Marienstras (1989) (through Lapshyna, 2019: 53) and Lapshyna (2019) that diaspora identities are not an immediate result of emigration, but rather that certain events need to take place so that a sense of kinship is developed among the expatriates.

In February, the outbreak of COVID-19 definitely put any residual mobilisations on hold. The spread of the pandemic caught all countries by surprise, but in a country on the abyss of financial breakdown like Lebanon and with limited public capabilities, social discontent is a ticking time bomb. The newborn Lebanese government adopted precautionary measures in time, being one of the first in the Middle East. The proximity 
with Iran, the epicentre of the pandemic in the region, so required. Actually, the first case of coronavirus in Lebanon was diagnosed to an Iranian traveller on 21 February.

The lockdown is a privilege that not everyone can afford in Lebanon. The global economic downturn prompted by COVID-19 has plummeted the already battered Lebanese pound by half. Thus, for many who live hand to mouth, the confinement is not a priority. Day after day more people in the poorest areas of the country like Tripoli, the Bekaa region, Saida and Akkar broke the confinement and went to the streets to desperately ask for humanitarian aid and access to their bank accounts as a small scale continuation of the Thawra.

The system resists thanks to backstage politics and citizen solidarity. At the beginning of April, the government tried to convince The World Bank (2020) to roll out an aid programme to palliate the collapse of the health system. In addition to that, the government also made calls to the citizens and especially to the diaspora to donate and politicians also made donations from their salaries (Chbaro, 2020). Charity organisations including partisan ones are also supporting vulnerable citizens (Perry \& Abdallah, 2020). But in a global crisis that also affects expatriates -a source of economic resilience for the country- all these initiatives are a drop in the ocean for a country where half of the population is expected to fall under the poverty line throughout this year (The World Bank, 2020).

In December 2019, several international online newspapers released an article based on the declarations by Information International (a Lebanese research centre) stating that the percentage of Lebanese expatriates had jumped by 42 points on the previous year (Osseiran, 2020). It is now uncertain by how much these numbers could be altered, given that many more might not be able to emigrate due to the deteriorating financial situation. In fact, the spread of the pandemic has made of Lebanon an attractive haven for some Lebanese expatriates, especially after the government's decision to repatriate them.

The decision was not clear from the beginning, though. Some sectors of the government were reluctant to repatriate the Lebanese abroad (Haddad, 2020). Michel Najjar, Minister of Public Works and Transportation declared: "We cannot repatriate all the Lebanese abroad; this is a massive issue considering the huge number of emigrants" ${ }^{2}$. But upon the threat by Speaker of the Parliament Nabih Berri to withdraw government support they eventually agreed that it was a right that should be protected. The reaction of Berri, leader of the Shii Amal party, must be considered in light of the important number of Lebanese Shia living in West Africa, whose contribution to the Lebanese economy represented between $7 \%$ to $10 \%$ of the total inflow of remittances in 2018 (M.R., 2020). Eventually, around 22,000 Lebanese expatriates from all over the world registered for repatriation (Haddad, 2020).

The repatriation mission was organised in different phases to avoid a collapse of the public health system, as feared by professionals in the sector (Newsom \& Daily Star, 2020). While some expatriates have congratulated the government for the strict measures enforced to contain the spread of the virus in the planes, others complained about the high fares caused by the lower number of passengers (Rose, 2020), which Tracy Saad denied to be like that. Infected returnees were sent to Rafik Hariri Hospital, the only public centre equipped to handle it $^{3}$, as $80 \%$ of Lebanese hospitals are private

\footnotetext{
2 "Lebanon to continue repatriation of coronavirus-stranded citizens abroad", 2020.

3 "Second Batch of Lebanese Expats Return Home, Health Minister Praises Efforts", 2020.
} 
(Chehayeb, April 31, 2020). So far, 16 Lebanon has contained the spread of the virus much better than other countries that enjoy larger resources. But one has also to consider that it is in the government's interest to regain the confidence of the Lebanese people given the events of the last months. Thus, a successful fight against COVID-19 might be a strategy to persuade the people of government credibility. But the prospects for the coming months leave nothing to rave about. On 21 May, the government failed to implement the pledged reforms that the people demanded in the Thawra (Azhari, 2020). And as Luna Safwan declared for The New Arab "Just because people are not protesting in the streets it does not mean that the idea of the October revolution is no longer there" (Massena, 2020).

So far, the success of the Thawra can be in terms of the consolidation of these diasporic relations between the residents and non-residents. The decentralisation and spontaneity of the protests have been a great asset because it confused the government and political leaders, that resorted to traditional violence and threat to contain the upheaval. But the prospects for the following times are not so cheerful. Tracy Saad said that "It's gonna take ages" to achieve any significant change and only $21 \%$ of the expatriates whom we surveyed believed that the Thawra would bring reforms. Professor Achcar pointed out as early of November 2019 that "leaderless movements" are efficient at the beginning of a revolution, but in further phases some kind of leadership structure is necessary to move forward, to make important decisions and setting clear agendas.

\section{Expectations for the Thawra}

Do you think that the protests will culminate with any social, political or economic progress for the Lebanese diaspora?

19 respostes
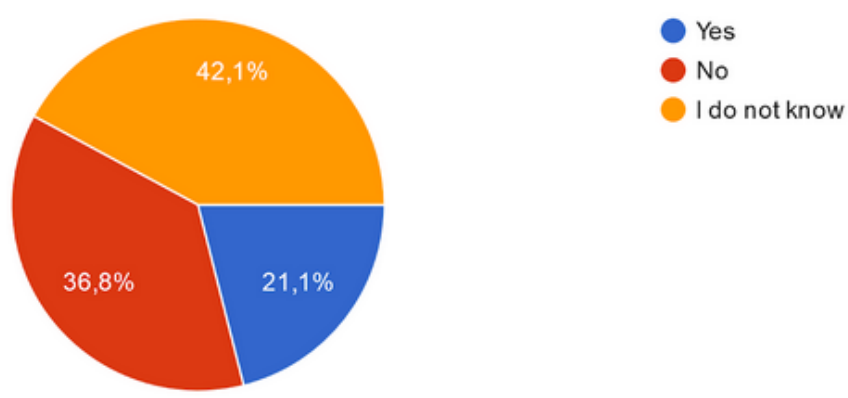

Figure 3: Perceived outcomes of the Thawra according to the sample.

At Meghterbin Mejtemiin they have a clear agenda: organising the diaspora to get it to vote what is in the interest of all and to endorse political movements that are ready to fight against the confessional power-sharing formula, sectarianism and the meddling of foreign powers in Lebanon. Overall MM fights for the independence of the country in a wide understanding of the concept. The ACL, which also supported the revolution from Barcelona organising mobilizations has a similar roadmap. Thus, the Thawra is not a contestation against the state, but exactly the contrary. It is a claim for the state and against sectarianism or the privatisation of the state by an oligarchy. 


\section{Results}

In this article, we have analysed the evolution of Lebanese diasporic relations since the outbreak of the October Revolution 2019 and with reference to the previous race for overseas voting and Lebanese emigration policies. The goal of the Thawra is to recapture the state with the cooperation of all social groups, including the expatriate community. It aims to end the atmosphere of protracted war that has characterised the post-war decades, build trust and reconcile the confronted groups, push for political regeneration, end a forced tradition of migration, rewrite the national narrative and build an independent state. Its most significant achievement so far is the consolidation of an anti-sectarian community awareness among the residents, between the residents and the expatriates and also in the diaspora. This new identity could not be understood without independent platforms like Meghterbin Mejtemiin, that has been coordinating the political mobilisation of expatriates in support of the Revolution and promoting crossconfessional solidarity in the context of the financial recession.

Diaspora policies and governance are only one of the many "pills" for strong state institutions. However, in an era of global mobility and inequalities, countries with a long history of emigration and sizeable diaspora like Lebanon have underestimated diasporaspecific policies to redistribute wealth and ensure equal rights for all its citizens. This is one of the many elements making of Lebanon a weak state. The poor citizen status of Lebanese expatriates is only one indicator of a wider shortage of political and civil rights in Lebanon and the impoverished Lebanese democracy. Inequalities in Lebanon are not only between the masses and the elites, but also between the residents and the expatriate community and among the different sects. The root cause is the confessional system implemented by Taif (1990), which limits the access to resources and services according to the religious sect that one belongs to by birth or marriage.

The answers obtained from the survey with the 19 Lebanese expatriates based in Catalonia confirmed that Lebanon does not fully enjoy inclusive, participatory and representative decision-making processes despite the overseas voting, because it continues to be sectarian, and they also denied it being a democratic state, which suggests the existence of backstage politics preventing real citizen influence on domestic politics and the Lebanese government.

\section{Participation in 2018 Elections}

Did you vote in last Lebanese elections?

19 respostes

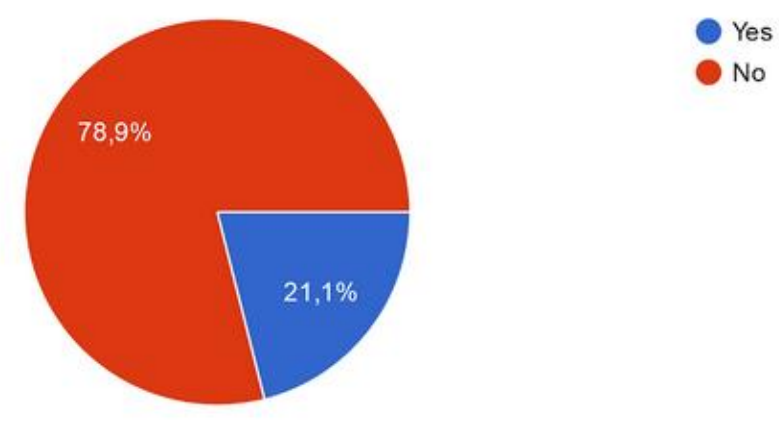

Figure 4: Results to question about electoral participation to last elections from the sample. 
The introduction of outside-country voting right in 2017 not trigger any more interest among Lebanese citizens for national politics, as Fakhoury suggested in 2018. However, the Lebanese Revolution does have; it has created a new national awareness between the residents and the expatriates. The motivations for participating in the Thawra are diverse: some felt with the responsibility to prove wrong those who deny the existence of a majority asking for change; others reported that they did not participate because they were hopeless while a third group was compelled to join the protests because for the first time they were not partisan but about human rights.

On the other hand, overseas voting has also upgraded their citizen status, which some downplay as a vote-buying strategy to preserve the benevolence of the diaspora, something that happened after some Arab Springs. That proves the lack of confidence with the Lebanese political class and that democracy and citizenship are not just about participation in elections but a contract that requires continuous reciprocity between citizens and the government. The diaspora has now the right to vote abroad and therefore, it should take advantage of that to bring its demands to the Parliament. However, the sectarian system continues to generate mistrust in the political class, discouraging political participation in decision-making processes. Hence, the country is at an impasse: the system and political class that it works for are not representative anymore of the popular demands. The upheaval is going to be a game of attrition against each other.

\section{Discussion}

The emergence of a 'diaspora sense of community' inexistent previous to the Thawra must be explained in relation to the emergence of a new national awareness at large. That confirms the ideas by Krawatzek \& Müller-Funk (2020) that political remittances during historic events have the capacity to change narratives of national belonging and start new identity constructions.

Diasporas and diaspora-specific policies or diaspora governance could be a nation-state building ingredient that redistributes wealth and ensures equal rights for all citizens, including expatriates. Residing abroad should not be a excuse to overlook the political and civil rights and for financial exploitation. The dignity of a state is a product of the reciprocity with its citizens. This is what the social contract and citizenship are about: having duties but also rights.

Well planned diaspora-specific policies are essential to regulate emigration relative to immigration and to protect the political and civil rights of expatriates and assist them in their departure, during their stay abroad, in their return process and in their reintegration. As such, they should also reverse brain drain. In order words, they should create employment opportunities in the homeland. But not only that: diaspora-specific policies should be able to manage the impact of political and economic remittances and technology and knowledge transfers in a sustainable way that benefits the state rather than undermines it. This means, for instance, reducing the financial reliance on expatriate remittances, which according to Pearlman (2014: 64) is one of the ways whereby diasporas might be undermining the nation-state, as in Lebanon's case they are used to reinforce sectarian clientelism that bypasses the power and need of public institutions and services, making it more vulnerable in global crises like COVID-19. But not only that, at a national level, diaspora policy planification could indirectly revitalise the international system, limiting the eroding impacts that ungoverned migration flows may have on states. 
At the end of the day, in the absence of a "world government", the state and international legislation remain central to diaspora governance (as its unit is the citizen). But at the same time, the strengthening or development of more specific international legislation with the political and civil rights of expatriates should be considered. That should include the unification of the understanding of 'diaspora' and 'expatriate' and their legal status at an international or global level, and the demarcation of policy principles and guidelines for equal rights and duties across different host and home countries.

Nevertheless, it makes no sense to implement diaspora-specific policies in the current Lebanese sectarian system because they would depend on the different status laws that fuel inequalities and emigration and they would not strengthen the state, but rather weaken it. It would only reinforce the sectarian system. Therefore, the first step towards overcoming inequalities and state weaknesses is the abolishment -or at least- the amendment of the Constitution, setting a clear strategy and deadlines to dismantle it, which is what The Taif Agreement failed at. In other words, reversing brain drain and forced expatriation hinges on a series of larger reforms including the abolishment of the power-sharing formula and differentiated personal status laws, and not only diasporaspecific policies.

Other recommendations that could be done to the Lebanese government include, but should not be limited to: the signature of the ICRMW, joining the IOM, fight against corruption and the return of stolen public funds and properties, update of the population census and intensive data collection with a gender-positive approach, reduction of the interest rates on bank deposits and remittances, restructuration of the national debt, introduction of a progressive taxation of incomes, interministerial cooperation and international cooperation in migration issues and a formal nationwide reconciliation process.

Both the SDGs and the Lebanese Revolution are a claim to "leave no one behind" and to save the fading Nation-state system, which makes them complementary. While the SDGs are calling for the political empowerment of expatriate citizens to retain state sovereignty and promote respect for human rights, the Lebanese Revolution is, in turn, defending a progressive agenda that has much in common with the SDGs and that is fundamental to their achievement: accountability and transparency in government practices among its principal demands. This is nothing but the integrative nature of the SDGs: action in one area leverages that in others. Taking seriously the implementation of The 2030 Agenda is relevant because it could be a rehearsal for national and international legislation more inclusive with expatriates as political, civil and migration governance actors.

The present survey is an attempt to bring together old and new debates about citizenship, civil and political rights, global mobility and activism under the case-study of a very recent event such as the Lebanese Revolution 2019. That makes it a very unique and hot-topic research but at the same time makes it limited in terms of testimonials, comparisons and forecasts. It would have been more enriching to survey a larger and more diverse sample of expatriates, to contrast the Lebanese Revolution with other diasporic relations cases -either in the Arab world or beyond- and to interview Lebanese government representatives about their views on the popular demands of the 'intifada', even if the study is diaspora-centered.

As shown by the global spread of COVID-19, the world has become a small and interdependent place, which makes us all more vulnerable. Although the pandemic has 
reached all corners of the planet, it has accentuated and unmasked old deficiencies and inequalities in weaker states like Lebanon. That defencelessness is the consequence of a missing social security system as evidenced during the lockdown. The fragile situation in which many people have been abandoned has unearthed interesting debates around the raison d'être of the state and the failure of the neoliberal system to provide wealth for all through private institutions. Lebanon's case alone is enough to show the consequences of dismantling the state and public welfare system. A public security system is essential to reduce inequalities because it ensures that all people are on the same page and have the same opportunities. Peace, justice and strong institutions are a symptom of and requirement to the reduction of inequalities.

Although it is difficult to tell whether the crisis of the state experienced by Lebanon is more a consequence of the harsh austerity measures and neoliberal policies, colonialism and foreign interventions or the confessional system on its own, the demands of the Lebanese people hint that the next independence to be accomplished is that of politics from religion. The Lebanese experiment with consocialism shows the overweighting constraints to ensure transparency and accountability and equal rights for all, which leaves the door open to other debates about what system is best to respect the traditions and beliefs of religiously diverse societies if not civil regimes. Last but not least, the identity crisis of the state and unconventional notions of citizenship that diasporas embody is also an invitation to reconsider what it means to be a citizen in the 21st century, on the basis of what criteria and by what entity shall any legal identity document be issued in an era of global mobility. This is something that we hope to hear more about in the following months.

\section{References}

Abi Yaghi, M., Catusse, M., \& Younes, M. (2017). From isqat an-nizam at-tai'fi to the Garbage Crisis Movement: Political Identities and Antisectarian Movements. Lebanon Facing The Arab Uprisings. Palgrave Pivot, London.

Achcar, G. (2019, November 14). More than just a "Spring": the Arab region's long-term revolution. Committee for the Abolition of Illegitimate Debt. Retrieved on 10 May 2020 from: https://bit.ly/2Mt3I9D.

Ahmad, TA. (2019, November 3). 'By the people, for the people,' Lebanese diaspora launches platform documenting Lebanon's revolution. Arab News. Retrieved on 26 February 2020 from: https://bit.ly/2XYZ6I6.

Ajroudi, A. (2018, May 2). Lebanon elections 2018: Politics as usual. AlJazeera. Retrieved on 26 February 2020 from: https://bit.ly/2XW8o7y.

Azhari, T. (2020, May 21). Lebanon PM marks 100 days in office as protesters storm ministry. Al Jazeera. Retrieved on 7 June 2020 from: https://bit.ly/375fdrQ.

Bdeir, A. (2019, October 24). The Lebanese Revolution: I am Terrified of the Morning After. Medium. Retrieved on 26 February 2020 from: https://bit.ly/309SKby.
Bourdieu, P. (1989) La Noblesse d'état: Grandes corps et esprit de corps. Paris: Les Editions de Minuit.

Chaaban, J., et al. (2018). Analysing Migration Policy Frames of Lebanese Civil Society Organizations (Working Paper No. 19). [Medreset, EU Horizon 2020, Programme for Research and Innovation]. Retrieved on 26 February 2020 from: https://bit.ly/2YOq0PO.

Chbaro, H. (2020, March 20). Lebanon asks citizens and diaspora for money to fight coronavirus. The Middle East Monitor. Retrieved on 7 May 2020 from: https://bit.ly/2BE8dql.

Chehayeb, K. (2020, April 16). Lebanon Is the Experiment That Shows Neoliberalism's Failure. The Century Foundation. Retrieved on 28 May 2020 from: https://bit.ly/2UdO9kN.

Chehayeb, K. (2020, April 31). 'You have no one but us': Lebanon's political elite resurrected amid coronavirus crises. The Middle East Eye. Retrieved on 7 May 2020 from: https://bit.ly/3eRDt3b.

Craven, C. R. (2018). Thinking About Governance Through Diasporas: Decentering the State and Challenging the External/Internal Binary. [SFBGovernance Working Paper Series, No. 76 Collaborative Research Center (SFB) 700, Berlin]. Retrieved on 19 May 2020 from: https://bit.ly/371WuNK. 
DiBartolomeo, A., Fakhoury, T., Perrine, D. (2010). CARIM Migration Profile: Lebanon. [European University Institute, Robert Schuman Institute for Advanced Studies]. Retrieved on 26 February 2020 from: https://bit.ly/2XASqAW.

Dibeh, G., Fakih, A., Marrouch, W., (2017). Decision to Emigrate Amongst the Youth in Lebanon. [CIRANO: Montréal]. Retrieved on 26 February 2020 from: https://bit.ly/3gXLOo0.

El Rajii, R., (2014). The Leaves of One Tree: Religious Minorities in Lebanon. Minority Rights Group International. Retrieved on 29 February 2020 from: https://bit.ly/2Y9OS82.

Fakhoury, T. (2014). Debating Lebanon's PowerSharing Model: An Opportunity or an Impasse for Democratization Studies in the Middle East? The Arab Studies Journal 22, 1.

Fakhoury, T. (2018). Lebanese Communities Abroad: Feeding and Fuelling Conflicts. Arab Reform Initiative. Retrieved on 26 February 2020 from: https://bit.ly/309hdxB.

Finaccord. (2017). Global Expatriates: Size, Segmentation and Forecast for the Worldwide Market. Finaccord. Retrieved on 4 June 2020 from: https://bit.ly/2XxBnji.

Ghosn, F. \& Khoury, A. (2011) "Lebanon after the civil war: peace or the illusion of peace?" The Middle East Journal 65(3), 381-397.

Haddad, S. (2020, April 2). Repatriation of the expatriates: a "first wave of 10,000" Lebanese expected between April 5 and 12. L'Orient-Le Jour. Retrieved on 7 May 2020 from: https://bit.ly/2XCEczH.

Hage, G. (2020, February 18). On Belonging to a Country That Cannot Keep Its Children. The Public Source. Retrieved on 6 June 2020 from: https://url2.cl/CWVkG.

Hourani, G. (2007). Lebanese Diaspora and Homeland Relations. Migration and Refugee Movements in the Middle East and North Africa Conference, 2325 October 2007. American University in Cairo, Egypt. Retrieved on 26 February 2020 from: https://bit.ly/2A3TG6K

Houri, W. el. (2019, November 8). Lebanon: a revolution redefining a country. Open Democracy. Retrieved 27 February 2020 from: https://bit.ly/3hjyjyl.

International Justice Resource Center, (n.d.). Immigration \& Migrants' Rights. Retrieved on 26 February 2020 from: https://bit.ly/2MtsJfi.

International Organization for Migration, (2018, May 22). Annual Diaspora Forum Programme. Retrieved on 26 February 2020 from: https://bit.ly/371lEvO.
International Organization for Migration (2019). Glossary on Migration. International Migration Law. Retrieved on 26 February 2020 from: https://bit.ly/307zxHz.

Jagarnathsingh, A. et al. (2018). Lebanon - Legal and Policy Framework of Migration Governance (Version V1). Respond. Retrieved on 26 February 2020 from: https://bit.ly/30sX0TV.

Kassir, S. (2013). Being Arab. London: Verso Books.

Krawatzek, F., \& Müller-Funk, L. (2020). Two centuries of flows between 'here' and 'there': political remittances and their transformative potential, Journal of Ethnic and Migration Studies, 46:6, 10031024

Lapshyna, I. (2019). Do Diasporas Matter? The Growing Role of the Ukrainian Diaspora in the UK and Poland in the Development of the Homeland in Times of War. 51-73. Retrieved 26 February 2020 from: 10.17467/ceemr.2019.04

LAU News, (2015, November 12). How engaged and effective is the Lebanese diaspora in Lebanon's politics? Retrieved on 26 February 2020 from: https://bit.ly/3dyUDCE.

Maksidi, S. (1997). Laying Claim to Beirut: Urban Narrative and Spatial Identity in the Age of Solidere. Critical Inquiry, 23(3), 660-705.

Marienstras R. (1989). On the Notion of Diaspora, in: G. Chaliand (ed.), Minority Peoples in the Age of Nation-States, pp. 119-25 London: Pluto Press.

Massena, F. (2020, April 1). 'We will rise again': Lebanon's revolution is on hold but far from over. The New Arab. Retrieved on 7 May 2020 from: https://bit.ly/2XAoJ36.

Migration Data Portal, (2020, March 23). Diasporas. Retrieved on 28 February 2020 from:https://bit.ly/3dCgXv9.

Ministry of Information, Republic of Lebanon, (2018, April 4). Lebanese electoral law 2018. Retrieved on 26 February 2020 from: https://bit.ly/3dw9P3g.

Molana-Allen, L. (2019, November 15). Lebanon protesters incensed by Aoun's 'insulting' remarks. Al Jazeera. Retrieved on 7 May 2020 from: https://bit.ly/2XxWEcs.

M. R. (2020, April 16). Lebanese Expats in Africa Trapped by Banking Restrictions. Le Commerce du Levant. Retrieved on 7 May 2020 from: https://url2.cl/w8ftJ.

Naji, R. (2020, March 7). The Lebanese Revolution Has its Own TV Stations. The 961. Retrieved on 7 May 2020 from: https://url2.cl/e5glr.

Nasrallah, C. (2016). Political Reading of the Right to Vote by the Lebanese Abroad. (Doctoral Thesis). Lebanese American University. Retrieved on 26 February 2020 from: https://url2.cl/pDY5b. 
National Democratic Institute, (2018). Lebanon 2018 Parliamentary Elections. Final Report. Retrieved on 26 February 2020 from: https://url2.cl/RJ9ca.

Newman, K. \& Plaza, S. (2013). What we know about diasporas and economic development. Migration Policy Institute. Policy Brief, 5. Retrieved on 12 February 2020 from: https://url2.cl/p1weG.

Newsom, N., \& Daily Star. (2020, April 1). Expat repatriation detrimental to public health: epidemiologist. The Daily Star Lebanon. Retrieved on 7 May 2020 from: https://url2.cl/ieetz.

Osseiran, H. (2020, January 30). 'I'm never coming back': Lebanon crisis fuels brain drain. The Daily Star Lebanon. Retrieved on 26 February 2020 from: https://url2.cl/mKDnB.

Pearlman, W. (2014). Competing for Lebanon's Diaspora: Transnationalism and Domestic Struggles in a Weak State. International Migration Review, 48(1), 34-75.

Perry, T., \& Abdallah, I. (2020, April 2). Coronavirus compounds Lebanon's woes, many struggles for food. Reuters. Retrieved on 7 May 2020 from: https://url2.cl/XqmDB.

Raad, M.R. (1998). The participation of Lebanese emigrants in the legislative elections of Lebanon. Beirut: American University.

Rose, S. (2019, October 10). Lebanon's cash-strapped millers demand bakers prove they have the dough. The National. Retrieved on 26 February 2020 from: https://url2.cl/QUM9s.

Sarsar, C et al (2019). The political participation of the diaspora of the Middle East and North Africa before and after the Arab uprisings. 3rd Global Campus Human Rights Journal, 3(1), 52-75.

Sewell, A. (2019, November 22). Expats organize to return to Lebanon for Independence Day. The Daily Star Lebanon. Retrieved on 7 May 2020 from: https://url2.cl/xKXFW.

Sökefeld M. (2006). Mobilizing in Transnational Space: A Social Movement Approach to the Formation of Diaspora. Global Networks 6 (3): 265-284.

Tabar, P. et al. (2012). Home politics abroad: the role of the Lebanese diaspora in conflict, peacebuilding and democratic development. [Lebanese American University, Institute for Migration Studies]. Retrieved on 26 February 2020 from: https://url2.cl/3u8gW.

Tabar, P., (2016). The Lebanese diasporic field: the impact of sending and receiving states, Immigrants \& Minorities, 34:3, 256-275.

Tabar, P. (2019). Transnational is not diasporic: A Bourdieusian approach to the study of modern diaspora. Journal of Sociology, 1-17.
The Taif Agreement. (1989, September) United Nations. Retrieved on 28 February 2020 from: https://url2.cl/vMKiF.

The World Bank, (2020, April 2). World Bank Deploys US\$40 Million in Emergency Response to Help Lebanon Face The Coronavirus Outbreak. Retrieved on 7 May 2020 from: https://url2.cl/C9kYm.

The World Bank Group \& KNOMAD (2020, April). Covid-19 Crisis Through a Migration Lens. Migration and Development Brief 32. Retrieved on 20 May 2020 from: https://url2.cl/HFICq.

United Nations. (1966, December 16). International Covenant on Civil and Political Rights, Treaty Series, 999. Retrieved on 26 February 2020 from: https://url2.cl/3gzda.

United Nations. (2015). Goal 10: Sustainable Development Knowledge Platform. The 2030 Agenda for Sustainable Development. Retrieved on 9 June 2020 from: https://sustainabledevelopment.un.org/sdg10.

United Nations Department of Economic and Social Affairs (DESA), International Organization for Migration (IOM) \& Organisation for Economic Cooperation and Development (OECD). (2019, September). SDG Indicator 10.7 Number of Countries with migration policies that facilitate orderly, safe, regular and responsible migration and mobility of people. Metadata Repository. Retrieved on 8 May 2020 from: https://url2.cl/LDEli.

Vohra, A. (2019, May 28). Lebanon's draft budget: A quick fix? Al Jazeera. Retrieved on 26 February 2020 from: https://url2.cl/klsbU.

Waters, G. et al. (2019, July 18). Syro-Lebanese Migration (1880-Present): "Push" and "Pull" Factors. Middle East Institute. Retrieved on 26 February 2020 from: https://url2.cl/s41L3.

Yan, V. (2019, October 27). 'Leave so we can come back', Lebanese diaspora joins the protest. The National. Retrieved on 26 February 2020 from: https://url2.cl/ldpuu.

Zakhour, M. (2020, March 05). This is How Lebanese Expats Stood in Solidarity with the Revolution. The 961. Retrieved on 10 May 2020 from: https://url2.cl/kb73v. 